\title{
Chicago, Newberry Library, Masi Fragm. 14 and the Fate of the Theodulf Bible in the Long Ninth Century
}

\author{
Evina Steinova \\ Postdoctoral Researcher, Huygens ING, KNAW, The Netherlands \\ evina.steinova@gmail.com
}

\begin{abstract}
Manuscript fragment Chicago, Newberry Library, Masi Fragm. 14 was previously misidentified as containing an unknown sermon or biblical excerpts. It is, in fact, a remnant of large-format deluxe Bible containing a set of Spanish prefaces to the Pauline epistles. These prefaces identify the deluxe codex as a descendant of a Theodulf Bible, a scholarly revision of the biblical text produced in the first decades of the ninth century by Theodulf of Orleans. Only seven copies of the Theodulf Bible are known. It is thus relevant that the Newberry fragment may have been dependent on another, previously unknown copy that was kept in one of the large monasteries of northwestern France, from which the fragment most probably comes. Because of its provenance from Haspres, the deluxe manuscript may have been produced in the nearby abbey of St. Vaast in Arras or perhaps by the community of the abbey of Jumièges.
\end{abstract}

\section{Keywords}

early medieval manuscript fragments - Theodulf Bible - Bible in the early Middle Ages - Carolingian manuscripts

According to the Codices Latini Antiquiores and Bernhard Bischoff's Katalog der festländischen Handschriften ${ }^{1}$ the Newberry Library in Chicago owns sixteen

1 I would like to thank Rosamond McKitterick for her precious comments and corrections. 
manuscript fragments that can be dated to before the year 90o. ${ }^{2}$ These fragments were cataloged for the first time in 1972 by Michael Masi, who assigned them their present shelf-marks and provided them with a short description and a tentative date. ${ }^{3}$ Masi identified one of these fragments, his number 14, as containing an unidentified sermon copied in the ninth century. In his Katalog, Bernhard Bischoff is only slightly more specific, considering the fragment to contain biblical excerpts (with a question mark) and pushing the date of the fragment to the turn of the ninth century. ${ }^{4}$ Since the publication of the first volume of Bischoff's Katalog, the fragment has not been studied further.

Today, many new facts about this fragment can be added, chiefly thanks to the manuscript digitization efforts of the last 15 years. These have made it far easier to identify the text it contains, and to compare it with versions in other manuscripts. Such a comparison establishes that Fragm. 14 contains neither a sermon, as proposed by Masi, nor a set of biblical excerpts, as Bischoff thought, but rather three prefaces to 1 Cor, such as would appear in a codex containing one or more books of the Bible. Masi Fragm. 14 is almost certainly a remnant of a rather large and lavish biblical manuscript that provides important insights into the history of Carolingian Bibles.

Scholars have widely recognized the central role that the Bible played in Carolingian intellectual life and written culture. ${ }^{5}$ It was, after all, towards the scriptural text and its correct performance in the liturgy that the emendatio spelled in central documents of Carolingian reform was to be applied. ${ }^{6}$ While the text of the Bible never underwent the same degree of uniformisation as other essential core texts of the Carolingian period (the Gregorian Sacramentary, the Rule of Benedict, canon law), the Carolingian reformers,

2 E.A. Lowe, Codices Latini Antiquiores. A Palaeographical Guide to Latin Manuscripts Prior to the Ninth Century (Oxford 1966), XI, pp. 20-21; B. Bischoff, Katalog der festländischen Handschriften des neunten Jahrhunderts (mit Ausnahme der wisigotischen). I: AachenLambach, Veröffentlichungen der Kommission für die Herausgabe der mittelalterlichen Bibliothekskataloge Deutschlands und der Schweiz (Wiesbaden 1998), pp. 196-98.

3 M. Masi, 'Newberry Mss Fragments, S. viI-S. Xv.', in: Mediaeval Studies, 34 (1972), pp. 98-112.

4 BK I 910.

5 See for example R. McKitterick, 'Carolingian Bible Production. The Tours Anomaly', in: The Early Medieval Bible. Its Production, Decoration and Use, ed. R. Gameson (Cambridge 1994), pp. 63-77, esp. p. 76; J. Contreni, 'The Pursuit of Knowledge in Carolingian Europe', in: The Gentle Voices of Teachers. Aspects of Learning in the Carolingian Age, ed. R. Sullivan (Columbus, OH 1995), pp. 106-41; R. McKitterick, 'The Carolingian Renaissance of Culture and Learning', in: Charlemagne. Empire and Society, ed. J. Story (Manchester and New York 2005), pp. 151-66.

6 B. Fischer, 'Bibeltext und Bibelreform unter Karl dem Grossen', in: Karl der Grosse. Lebenswerk und Nachleben. II. Das geistige Leben, ed. H. Beumann et al. (Düsseldorf 1965), II, p. 156 . 
nevertheless, can be credited with inaugurating several trends that affected the shape and form of the Latin Bible, in particular the promotion of a specific version of the Latin Psalter, the Gallicanum, and the popularization of pandects, one-volume copies of the entire Bible. The call for emendatio also produced two important revisions of the Bible by leading Carolingian scholars from the court of Charlemagne: Alcuin of York and Theodulf of Orleans. ${ }^{7}$ These Carolingian revisions were influential, not only as far as their text was concerned, but also in the choice of books included in the scriptural canon, the order in which they were placed, and the addition of auxiliary materials such as prefaces, summaries, and text-divisions. Both Alcuin and Theodulf, moreover, opted for the technologically innovative form of a pandect for their revisions. Importantly, the two Bibles were not produced for a small circle of intellectuals, but were rather enterprises that dynamically evolved to be copied in a highly-systematic fashion and dispatched from a central hub.

Especially the later embodiments of Alcuin's Bible, the Tours Bibles, demonstrate the capabilities of large Carolingian scriptoria for mass production and dissemination. While other Carolingian scriptoria somewhat pale in comparison with the impressive output of Tours, many can be shown to have devised their local biblical pandects or corpora responding to the call for emendatio and contributing to a complex mosaic of biblical text versions, book orders, auxiliary tools and manuscript formats that characterize the biblical landscape of the Carolingian world. ${ }^{8}$ The Masi fragment of the Bible represents one of the tesserae in this mosaic.

\section{The Format, Script, and Content of Masi Fragm. 14}

As it survives today, Chicago, Newberry Library, Masi Fragm. 14 is a half-leaf of a large format codex. The fragment measures $212 \times 282 \mathrm{~mm}$. The text is laid out in two columns, each $102 \mathrm{~mm}$ wide, with the outer margin almost intact

7 The Alcuin Bible is discussed in detailed in B. Fischer, Die Alkuin-Bibel (Freiburg 1957); B. Fischer, 'Die Alkuin-Bibeln', in: Lateinische Bibelhandschriften Im Frühen Mittelalter, Vetus Latina. Aus Der Geschichte Der Lateinischen Bibel, 11 (Freiburg im Brisgau 1985), pp. 203403. The most recent accounts of the Theodulf Bible are E. Dahlhaus-Berg, Nova antiquitas et antiqua novitas. Typologische Exegese und isidorianisches Geschichtsbild bei Theodulf von Orléans, Kölner historische Abhandlungen, 23 (Cologne 1975); Pseudo-Jerome, Quaestiones on the Book of Samuel. Studia Post-Biblica, 26, ed. A. Saltman (Leiden 1975).

8 This mosaic of Carolingian biblical manuscripts was masterfully captured in B. Fischer, 'Bibelausgaben des frühen Mittelalters', in: La bibbia nell'alto medioevo,10 (Spoleto 1963), pp. 519-6oo, esp. pp. 89-97; and especially Fischer, II. 
at $53 \mathrm{~mm}$, the intercolumn of $25 \mathrm{~mm}$, and the inner margin missing for the most part. The current fragment contains twenty lines of text in a relatively large script.

The script is a well-formed Caroline minuscule with several notable features. The scribe uses both a straight-backed and an uncial $d$, the latter with a tail pointing to ten o'clock. The $g$ has a closed upper and open lower loop. The $x$ is composed of two equal strokes, none of which descends below the baseline. Letters $b, d, h$, and $l$ have modestly clubbed ascenders.

Abbreviations and ligatures are relatively scarce as can be expected from a deluxe biblical manuscript. The final tur is abbreviated with a 2-shaped sign above the last letter and on one occasion, the final que appears as q: On the verso side, one can note an $u e$-nexus and an $a e$-nexus at the end of the first lines of each column, but the $a e$ is otherwise never represented with $e$ caudata. The 02 -ligature for or appears as does et-ligature and rum-ligature, but one can note that $e t$ is often written in full. Only two ligatures are rather prominent and give the script a unique appearance. First, when the $r$ enters into a ligature with the following vowel, as happens often, it acquires an unusually pronounced spur. Second, the scribe ligates $s$ and $t$, but the horizontal stroke of $t$ never touches the $s$. In fact, the ligature prompts him (or her) to push the two letters apart, which gives the script a slightly unbalanced appearance. On the verso of the fragment, titles identifying the Old Testament book from which testimonies in 1 Cor come were executed in uncial and the title of the following section at the bottom of the second column in small rustic capitals.

There is no trace of rubrication, even where it may be expected: the capitula of 1 Cor on both recto and verso are missing their numbers. Since spaces were left blank before the first letter of some of the capitula, the rubrication was perhaps planned but not carried out.

Overall, the script can be described as elegant, the scribe as well-trained and disciplined (there are very few errors, which are treated carefully) and the manuscript from which Masi Fragm. 14 comes as a high-grade product. Despite the regularity and clarity of the script, the codex should be placed closer to the tenth century than into the ninth century. Bischoff's verdict that it can be dated to the turn of the ninth century accords with this conclusion. As for the contents of the fragment, the three short texts it contains can be identified as:

a) summaries to 1 Cor

recto, ll. 1a-20a: et sitimus et nudi sumus ... habeat et mulier sui corporis (to 1 Cor 4-7)

(summaries to 1 Cor 8-9 missing where the leaf is cropped) 
recto, ll. 1b-2ob: faceret et qui diu currunt ... De spiritalibus et quia (to 1 Cor 10-12)

(summaries to 1 Cor 13-14 missing where the leaf is cropped) verso, ll. 1a-20a: nolite pueri effici sensibus ... De pri[mo] (to 1 Cor 15-18)

The text of these summaries has been edited in Donatien de Bruyne, Summaries, divisions and rubrics of the Latin Bible, pp. 320-26. The full title not found in the Newberry fragment is Incipit capitulatio ad Corinthios.

b) a list of Old Testament passages quoted in 1 Cor verso, ll. 1b-19b: in Domino glorietur. IN ESAIA. Quae ... IN OSEE. Absorta est in victoria mors, ubi est mors victoria tua

The text of this preface was edited in Donatien de Bruyne, Prefaces to the Latin Bible, p. 250. The full title not found in the Newberry fragment is Haec testimonia de veteri testamento conpraehensa sunt in epistola ad Corinthios. This preface is one of a set that was attached to all Pauline epistles.

c) a list of New Testament figures mentioned in 1 Cor verso, l. 2ob: QVOS SANCTORVM COMMEMORAT APOSTO [LVS]

The text of this preface was edited in Donatien de Bruyne, Prefaces to the Latin Bible, p. 251. Only the title is present in the Newberry fragment. The full title is: Quos sanctorum commemorat apostolus in epistula ad Corinthios I. Just as Haec testimonia, this text is one of a set that was attached to all Pauline epistles.

The three prefaces, in this combination and order, belong to the fifth-century redaction of the Pauline epistles by the Spanish bishop Peregrinus. ${ }^{9}$ They can be found in two types of biblical manuscripts. One group are manuscripts from Spain such as Cava dei Tirreni, Badia di Cava, MS 1 (Codex Cavensis), 9th century and Madrid Biblioteca Nacional, Vitr. 13.1 (Codex Tolentanus), 1oth century that represent a continuation of the Spanish tradition in the region of its origin. The other group of biblical manuscripts containing the same prefatory material are the Theodulf Bibles. They are, in fact, the oldest surviving witness for items b) and c) and also seems to have been the unique entry point for the Peregrinus material into the Carolingian area. ${ }^{10}$

$9 \quad$ Fischer, art. cit. (n. 7), pp. 47-9.

10 The witnesses containing the same material from beyond the Pyrenees can be all shown to be dependent on Theodulf. They are not discussed in S. Berger, Histoire de la Vulgate pendant les premiers siècles du moyen âge (Paris 1893). 
Our fragment shows no link with the Iberian Peninsula in its script, orthography or other features. On the contrary, Masi Fragm. 14 is a full-blooded Carolingian manuscript and therefore it is reasonable to assume that it is a descendant of the Theodulf Bible rather than of manuscripts whose circulation was restricted to the Iberian peninsula. Given how relatively scarce the traces of Theodulfian scriptural material are, the identification of the text in the Newberry fragment is particularly valuable. It promises to shed light on the fate of Theodulf's scriptural enterprise in the hundred years or so following its emergence.

One possibility that can be excluded outright is that Masi Fragm. 14 is itself a remnant of a Theodulf Bible. Palaeographically and codicologically, the Bibles from the workshop of the Visigothic bishop form a homogeneous group within which our fragment does not fit. ${ }^{11}$ In the first place, the Theodulf Bibles were produced either at the Abbey of St. Mesmin at Micy or at Theodulf's scriptorium at Orleans in the first decades of the ninth century, while our fragment cannot be assigned to these centres and was copied nearly one hundred years later. ${ }^{12}$ More importantly, all the codices produced for Theodulf have an identical format, their pages measuring 320-340 × 230-250 mm. Being modestly sized to accommodate the text of the entire biblical canon and several accessory texts, these pandects were copied in a minute hand that compressed between 60 and 62 lines of text into either two or three columns. Even though only a part of the leaf is preserved in the Newberry library, it is clear that it comes from a much larger book (width of $282 \mathrm{~mm}$ without the inner margin) and that this book was copied with fewer lines per column (the writing columns could not have contained more than 40 lines).

There are additional palaeographical and codicological traits that distance our fragment from Theodulf Bibles and may be instructive to consider. While only modestly decorated, Theodulf Bibles were carefully rubricated and equipped with running titles. Our fragment, as noted above, lacks rubrics entirely, even for titles and for capital letters indicating the beginning of a new summary. There is no running title, either because it was never planned or never executed. Furthermore, one can note that in the Theodulf Bible, prefaces were copied in a smaller hand than the scriptural text. While we cannot know how the text of the Pauline epistles would have been presented in the manuscript from which the Newberry fragment comes, it is unlikely that the large size of script visible in the fragment represents a smaller script. Most probably, the scriptural text and the prefaces were copied in the same size of script.

\footnotetext{
11 Fischer, art. cit. (n. 8), pp. 175-77.

12 Dahlhaus-Berg, op. cit. (n. 7), pp. 39-76.
} 
Thus, while the Newberry fragment textually resembles a Theodulf Bible, it is in all likelihood its second- or a third-generation descendant. Such descendants transmitting partly or wholly Theodulf's project in novel formats are known from the following centuries albeit relatively rarely.

\section{The Theodulf Bible and its Influence on Carolingian Biblical Codices}

The biblical revision of Theodulf of Orleans circulated far less widely than the contemporary revision of the Bible carried out by Alcuin. In contrast to fortynine surviving Tours Bible (to which one must also add twenty-five Gospel books produced by the same scriptorium of Tours), only seven manuscripts of the Theodulf Bible are known. ${ }^{13}$ The influence that Theodulf's text-versions of the Bible exerted on biblical manuscripts or exegesis produced in the ninth century and after has been studied only to a limited degree. Caroline ChevalierRoyet has shown that Angelomus of Luxeuil used a Theodulf Bible when producing his commentary on the Kings. ${ }^{14}$ According to Rosamond McKitterick, the makers of Paris, Bibliothèque nationale de France, Lat. 2 (870s, St. Amand) were familiar with the Theodulf Bible. ${ }^{15}$ The pandect Bern, Burgerbibliothek, A 9 (1oth/11th century, Vienne) was copied from a Theodulf Bible as were some of the books in the two-volume Corbie Bible, Paris, Bibliothèque nationale de France, Lat. 11532-33 (9th century, 2/4). ${ }^{16}$ Another Theodulfian pandect was used in the twelfth century at Clairvaux to correct their Psalterium iuxta

13 Six of them are known since the second half of the twentieth century. These are, in the chronological order assigned to them by Dahlhaus-Berg: Stuttgart, Würtembergische Landesbibliothek, HB II 16, London, British Library, Add. 24142, Le Puy, Trésor de la Cathédrale, Paris, BnF, Lat. 938o, Paris, BnF, Lat. 11937, and Kopenhagen, Königliche Bibliothek, NKS 1; Dahlhaus-Berg, op. cit. (n. 7), pp. 49-53. Fragments of a seventh manuscript have been recently unearthed in the Staatsarchiv and Zentralbibliothek of Solothurn; I. Holt, Handschriftenfragmente in der Zentralbibliothek Solothurn. Eine Auswahl, Veröffentlichungen der Zentralbibliothek. Kleine Reihe, 2 (Solothurn 2012), pp. 22-23. These fragments are digitized at: https://www.e-codices.unifr.ch/en/sl/ooo3/8.

14 C. Chevalier-Royet, 'Les révisions bibliques de Théodulf d'Orléans et la question de leur utilisation par l'exégèse carolingienne', in: Études d'exégèse Carolingienne. Autour d'Haymon d'Auxerre, ed. S. Shimahara (Turnhout 2007), pp. 237-56.

15 McKitterick, art. cit. (n. 5), p. 68.

16 Fischer, art. cit. (n. 8), p. 176; and Berger, op. cit. (n. 10), pp. 105-6. The Bern manuscript is digitized at: https://www.e-codices.unifr.ch/en/bbb/Aooog/289r/o/Sequence-44; the Parisian manuscripts at: https://gallica.bnf.fr/ark:/12148/btvib9080818z.r=\%22Latin\%20 $11532 \% 22$ ? rk=21459;2. 
Hebraeos. ${ }^{17}$ The influence of Theodulf's text-version, it seems, was restricted largely to France, where the pandects were produced and where all but one remained during the Middle Ages.

Outside France, knowledge of the Theodulfian text has been documented only in the Bodensee region. The oldest Theodulf Bible, Stuttgart, Würtembergische Landesbibliothek, HB II 16, was kept at Constance from at least the fourteenth century and perhaps significantly earlier. ${ }^{18}$ The fragments of a Theodulf Bible discovered at Solothurn may have been present in the library of the cathedral of St. Ursus in Solothurn from the fifteenth century and perhaps significantly earlier. ${ }^{19}$ Furthermore, H. J. Frede has shown that a now-lost Theodulf Bible was used in the 810 s or the 820 s to correct the readings of the Pauline Epistles in the same region. ${ }^{20}$

This is as far as scholars have been able to trace the influence of Theodulf's scriptural text, the element of his revision of the Bible that interested them the most. However, the text-version of the Bible and its variants are not the only measure of the dissemination and impact of Theodulf's project.

The scholarly apparatus with which Theodulf equipped his pandects, including prefaces such as those preserved in the Newberry fragment, are equally valuable in revealing who may have possessed and used a manuscript from the workshop of the bishop of Orléans. True, paratextual material has the habit of travelling from Bible to Bible and its presence, therefore, does not guarantee that one is looking at a codex that would have transmitted a Theodulfian text-version (as should be suspected to be the case with the Newberry fragment). However, since the point of origin of such material must have been ultimately a codex of the Theodulf Bible, it has, too, a value as an indicator of the reach of Theodulf's scriptural project, perhaps even more so than the textual variants of the biblical text, because medieval manuscript producers may have been more prone to adopt interesting prefaces and apparatus than the biblical text itself.

In this respect, it can be noted that several St. Gallen codices copied in the ninth and twelfth centuries received the Spanish prefaces to the Pauline Epistles even though they do not transmit Theodulf's text-version. Stuttgart, Würtembergische Landesbibliothek, HB II 54 was produced as a part of a

17 Fischer, art. cit. (n. 8), p. 177.

18 It has been identified as an item in the 1343 catalogue of the Dombibliothek; Die Handschriften der Württembergischen Landesbibliothek Stuttgart Bd. 2, T. 1, ed. H. Boese (Wiesbaden 1975), p. 19.

19 A. Schönherr, Die Mittelalterlichen Handschriften der Zentralbibliothek Solothurn (Solothurn 1964), pp. 204-205.

$20 \quad$ H.J. Frede, Altlateinische Paulushandschriften, Vetus Latina, 4 (Freiburg 1964), pp. 55-56. 
multi-volume Bible in the 820s and contains all three prefaces also found in the Newberry fragment. ${ }^{21}$ St. Gallen, Stiftsbibliothek, MS 83 is a part of a sixvolume corpus that was produced under Abbot Hartmut in the second half of the ninth century. It contains only the first two prefaces present in our fragment, the summaries and the overview of the Old Testament references. ${ }^{22}$ St. Gallen, Stiftsbibliothek, MS 76 from the twelfth century is a pandect Bible that contains only the prefaces found in the Hartmut corpus and which was probably copied from the ninth century manuscript. ${ }^{23}$ The three St. Gallen biblical manuscripts may well owe their Theodulfian prefaces to the same codex that was identified by Frede as having been present in the Bodensee region at the beginning of the ninth century.

Masi Fragm. 14 is a remnant of another biblical codex that was equipped with the same prefaces as the St. Gallen Bibles. Its relationship to the St. Gallen group can be excluded on textual grounds. It can be shown on the basis of a comparison of the second preface(Old Testament testimonies) in the Newberry fragment, the two oldest St. Gallen manuscript, and three of the Theodulf Bibles (Paris, BnF, Lat. 9380, Stuttgart, Würtembergische Landesbibliothek, HB II 16, and London, British Library, Add. 24142) that Masi Fragm. 14 aligns more closely with the Theodulf Bibles than with the St. Gallen group, which is characterized by several notable variant readings not reflected in our fragment. ${ }^{24}$ The manuscript from which the Newberry fragment comes, therefore, reveals that the same development that can be observed at St. Gallen in the ninth century took place independently elsewhere. This is a valuable discovery, given the assumptions hitherto about the limited influence of Theodulf's project on Carolingian and post-Carolingian Bibles.

21 The manuscript is digitized at: http://swb.bsz-bw.de/DB=2.1/PPNSET?PPN=349887195\& INDEXSET $=1$.

22 The manuscript is digitized at: https://www.e-codices.unifr.ch/en/csg/oo83/52/o/ Sequence-278.

23 The manuscript is digitized at: https://www.e-codices.unifr.ch/en/csg/oo76/815/o/ Sequence-1598.

24 Paris, BnF, Lat. 9380, Stuttgart, Würtembergische Landesbibliothek, HB II 16, and London, British Library, Add. 24142 are the only three manuscripts of the Theodulf Bible that both contain the second preface to 1 Cor and are available online. The Paris codex is available at: http://gallica.bnf.fr/ark:/12148/btvib8452776m/f588.image.r=\%22Latin\%209380\%22; the Stuttgart codex is available at: http://dfg-viewer.de/show/?tx_dlf\% $\%$ Bpage $\% 5 \mathrm{D}=348 \&$ tx dlf\%5Bid\%5D=http\%3A\%2F\%2Fdigital.wlb-stuttgart.de\%2Fmets\%2Furn\%3Anbn ${ }_{0}$ Ade $\% 3$ Absz $\% 3$ A24-digibib-bsz3533380287\&tx_dlf\% $\%$ Bdouble $\% 5 \mathrm{D}=0$ \& c Hash =d8c19e209a78b4b2096662654e 48474a; and the London codex is available at: http:// www.bl.uk/manuscripts/Viewer.aspx?ref=add_ms_24142_fsooir. 
Just as the presence of Spanish prefaces in St. Gallen manuscripts mentioned above corroborates the evidence for the existence of an eighth but now-lost Theodulf Bible that was possibly available at St. Gallen in the first decades of the ninth century, the Masi fragment may similarly point to yet another manuscript of the Theodulf Bible (that is, a ninth), available at the centre that produced the book from which only a half-leaf survives today in the Newberry library. Where the codex may have been produced is difficult to assess from script alone. Even Bernhard Bischoff did not wish to attribute the fragment to any particular area or scribal centre. Nevertheless, hints as to the possible area of origin are provided by two notes that were inserted on the verso of our fragment. The first note reads: 'Déclaration des censes et rentes des fiefs appartenant à $[\ldots] 1[$ [7? $] 3^{2}{ }^{\prime 25}$ The second note repeats the same words: 'Déclaration des censes et rentes des fiefs appartenant', and a different hand adds the name 'Haspres'. ${ }^{26}$

The priory of Haspres is situated in northern France close to Cambrai. In the early Middle Ages, it was subordinate to the Abbey of Jumièges in Normandy. When the Vikings attacked Jumièges in 841 , fleeing monks found refuge in Haspres, bringing along their prized possessions including the relics of Saints Achard and Hugo. They remained in Haspres until the 940s, when the community made attempts to return to Jumièges and re-establish their old house, an effort that eventually proved successful. Jumièges retained Haspres until 1024 when the priory passed into the possession of the Abbey of Saint Vaast in Arras. ${ }^{27}$

The notices situate the codex from which the Masi fragment comes to northwestern France. It may have been produced at Saint Vaast, which avoided the fate of Jumièges and possessed a scriptorium capable of producing a largeformat biblical codex in the first half of the tenth century. ${ }^{28}$ It should be noted

25 I would like to thank my colleagues Anna Dorofeeva and Warren Pezé for kindly helping me with deciphering this note.

26 The same notice can be found in other documents pertaining to the priory of Haspres, see http://genealegrand.pagesperso-orange.fr/haspres/haspres_relief_prevote.htm.

27 For the history of the priory, see L. Musset, 'Monachisme d'époque franque et monachisme d'epoque ducal en Normandie. Le problème de la continuité', in:Aspects du monachisme en Normandie. Actes du Colloque scientifique de l'Année des abbayes normandes, Caen, 18-20 octobre 1979. IV e-XVIII $^{e}$ siècles, ed. L. Musset, Bibliothèque de la Société d'histoire ecclésiastique de la France (Paris 1982), pp. 55-74, esp. pp. 58-59; J-F. Lemarignier, 'Le prieuré d'Haspres, ses rapports avec l'abbaye de Saint-Vaast d'Arras et la centralisation monastique au début du XII e siècle', in: Revue du Nord, 29 (1947), pp. 261-68.

28 The scriptorium of Saint Vaast is discussed in D. Escudier, 'Le scriptorium de SaintVaast d'Arras des origines au XII ${ }^{\mathrm{e}}$ siècle. Contribution à l'étude des notations neumatiques du nord de la France', in: Positions des thèses de l'École des Chartes, 1970, pp. 75-82; 
that Bischoff thought that Paris Lat. 11532-33 may have been produced at Arras. ${ }^{29}$ The Theodulf Bible that served those who produced this two-volume Bible could have been, if Bischoff is correct, related to our fragment. Yet, neither the script of Paris Lat. 11532-33 nor of the surviving manuscripts attributed to Saint Vaast with certainty yields notable similarities with the script of the fragment.

There is also a distant possibility that the biblical codex from which the Newberry fragment comes was copied by the community of Jumièges in their exile at Haspres and remained at the priory until it was scraped and used as a cover of a fascicle of fiscal documents in the eighteenth century. If such a hypothesis can be accepted, it would explain why the fragment cannot be localized. There are effectively no manuscripts that can be connected with the scriptorium of Jumièges in the second half of the ninth and the first half of the tenth century. An exception may be Bamberg, Staatsbibliothek, Patr. 134, which was dated by Bischoff to the first half of the tenth century and which contains the vitae of Jumiéges saints, Achard and Hugo, as well as of Saint Filibert, the founder of the abbey. ${ }^{30}$ However, the script of this manuscript does not resemble the script of the Newberry fragment. Overall, the paleography of the fragment, especially the pronounced spurs on the letter $r$, make it difficult to attribute to known scriptoria of northern France. ${ }^{31}$

Given the provenance of the fragment, it is possible that our fragment descends from a pandect different from all of the surviving copies of the Theodulf Bible. Most of them survive from further south, such as Le Puy, Orléans, and Carcassonne. The northernmost copies are Paris, BnF, Lat.11937, which was kept at Saint-Germain-des-Prés, and London, British Library, Add. 24142, which was kept at Saint Hubert in the Ardennes. Furthermore, a comparison shows that our fragment is more closely related to Paris, BnF, Lat. 938o from Orléans than to the Saint Hubert manuscript (the manuscript from Saint-Germain-des-Prés is cropped).

R-M. Normand-Chanteloup, D. Escudier, and L. Wiart, Enluminures arrageoises. Le scriptorium de l'abbaye Saint-Waast d'Arras des origines au XII ${ }^{e}$ siècle (Arras 2002).

29 BK III 4687.

3o Bischoff, op. cit. (n. 2) p. 53 .

31 It should be perhaps added that the spurred $r$ was in use in Germany, especially in Bavaria, from the second half of the ninth century. Fischer notes that fragments of two biblical codices produced in Arras or with the aid of scribes trained at Arras are now preserved in Bavaria, which may indicate a connection between the regions; Fischer, art. cit. (n. 8), p. 189 . 


\section{The Masi Biblical Codex}

What kind of book was the original codex from which Masi Fragm. 14 survives? Since the fragment is laid out in two columns and we possess several manuscripts with which it can be compared, it is possible to reconstruct the layout of a page of its mother codex and say something about its codicological properties. Indeed, even though only a half-leaf today survives of the original codex to which Masi Fragm. 14 once belonged, it is sufficient to enable many useful observations to be made about the shape and size of this book.

A comparison with Paris, BnF, Lat. 9380, the only manuscript of the Theodulf Bible available online that was laid out in two columns like our fragment, shows that the 20 lines of text surviving in each of the columns of the fragment correspond to seven or eight lines of a column of text of the Parisian pandect. Five or six lines of text are missing where the Newberry leaf was cropped. The original book could not have more than 36-38 lines of text in two columns. Depending on how large the lower margin may have been, the leaf of the Newberry codex can be estimated to have measured something like $420-440 \mathrm{~mm}$. The width of the original leaf was probably between 300 and $335 \mathrm{~mm}$, depending on how large the missing inner margin would have been.

The Bible from which Masi Fragm. 14 was taken was, then, a large-format Bible, roughly one third larger in dimensions than a Theodulf Bible. The format itself is not unusual for a biblical codex. Carolingian scriptoria could produce Bibles that were larger. The leaves of Tours Bibles would measure around $480 \times 375 \mathrm{~mm}$. Yet, what is characteristic for these large pandects is that, in order to accommodate the entire biblical corpus, they contain 50-6o lines of text per column, certainly more than 40 lines. The Tours Bible copied in two columns and $5^{0-52}$ lines could be squeezed into roughly $45^{0}$ leaves. ${ }^{32}$ The scribes of the Theodulf Bible were able to achieve an even greater feat: by copying 6o-62 lines in two or three columns and using a smaller script than the Tours Bible, they contained the biblical canon in under 400 leaves while keeping the book they produced modestly sized. At less than 40 lines and with each line measuring almost $95 \mathrm{~mm}$, it is hard to imagine that the codex from which the Masi fragment 14 came could be a pandect. This is also clear from the fact that the text reconstructed as present on the two sides of the leaf partially preserved in the Newberry library covers less than a column of text in Paris,

32 See D. Ganz, 'Mass Production of Early Medieval Manuscripts. The Carolingian Bibles from Tours', in The Early Medieval Bible. Its Production, Decoration and Use, ed. R. Gameson, Cambridge Studies in Palaeography and Codicology (Cambridge 1994), pp. 53-62, esp. p. 55 . 
BnF, Lat. 9380. Even at most generous estimates, the codex, from which the leaf came, if it were a pandect, would have to consist of 800-100o leaves. Certainly, no extant Carolingian manuscript has as many folios as this in one volume.

There is another significant difference between the Theodulf Bible, always a pandect, and this codex, which was surely one part of a multi-volume Bible. In its layout, it also differs from the other manuscripts discussed above. Bern A 9, the manuscript copied around the turn of the tenth century at Vienne, has pages similar in dimensions to the Newberry manuscript $(445 \times 350 \mathrm{~mm})$ and laid out in two columns, but it is a pandect and has 54 lines of text in each column. Closer still is the two-volume Paris, BnF, Lat. 11532-33 with pages measuring $450 \times 360 \mathrm{~mm}$ and laid out in two columns, thus comparable to the Newberry codex, but with 47 lines of text per page. The page of Stuttgart HB II 54 measures only $300 \times 210 \mathrm{~mm}$ and has fewer than 25 of text in long lines. In St. Gallen 83 , the text was copied on pages measuring $405 \times 305 \mathrm{~mm}$ in two columns with 28 lines. Fortunately, however, Berger's handlist of Vulgate manuscripts lists four manuscripts of dimensions and writing surface comparable to the Newberry fragment: ${ }^{33}$

Basel, Universitätsbibliothek, B I 6 (9th/1oth century, West Germany, perhaps Strassburg): 153 fols. (incompletely preserved), $480 \times 340 \mathrm{~mm}$ $(410 \times 255 \mathrm{~mm})$, 40 long lines, the second part of a two-volume Bible Metz, Bibliothèque municipale, MS 7 (8th/9th century, Metz): 359 fols., $450 \times 330 \mathrm{~mm}(380 \times 250 \mathrm{~mm}), 40$ lines, 2 columns, the second part of a two-volume Bible

Milan, Biblioteca Ambrosiana, E 26 inf. (9th/1oth century, Bobbio): 307 fols., $445 \times 295 \mathrm{~mm}(365 \times 210 \mathrm{~mm}), 43$ lines, 2 columns, the second part of a two-volume Bible

Paris, BnF, Lat. $45+93$ (9th century, 1/2, St. Denis): $262+261$ fols., $510 \times 345 \mathrm{~mm}(400 \times 260 \mathrm{~mm})$, 42 lines, 2 columns, two-volume Bible

One can immediately note that all of the codices with dimensions and writing surface comparable to our fragment are two-volume Bibles. Thus, to the extent that dimensions, even if approximate, can be used as a guide, the book from which the Newberry fragment came may have likewise been a second part of a two-volume Bible. It is also revealing that two of the four codices were produced at around the same time as the book from which our fragment comes. Nevertheless, none of the four manuscripts is similar to Masi Fragm. 14

33 Berger, op. cit. (n. 10), pp. 374-422. 
paleographically or textually; they show no traces of affiliation with the Theodulf Bible nor do they contain Theodulfian prefaces.

\section{Conclusion}

Chicago, Newberry Library, Masi Fragm. 14 provides us with useful insight into the afterlife of Theodulf's biblical revision in the Carolingian area. The community that produced the large-format Bible in several volumes seems to have been situated in a region from which no manuscript of the Theodulf Bible has been known to survive. The fragment is an indirect piece of evidence that at least one of the abbeys situated in the northwestern part of Frankish territory may have possessed a Theodulf Bible, a fact that is not entirely surprising since many rich and important monastic communities were situated in this area. Indeed, the community that copied the manuscript from which the Newberry fragment survives seems to have been well-endowed and included highly skilled scribes. While the large script used for copying the presumably two-volume Bible from which the Newberry fragment comes could have been taken to indicate intended liturgical use, the presence of elaborate prefaces is more fitting for a scholarly tool.

This short investigation of the Masi fragment also shows the value of further study of biblical prefaces in Carolingian and post-Carolingian biblical manuscripts. It is not impossible that the Spanish prefaces to Pauline epistles introduced by Theodulf of Orléans were more influential within the Carolingian and post-Carolingian world than has previously been thought. Their further study may, moreover, have more to offer than simply textual variants that would identify a particular manuscript as holding a Theodulfian text-version or having been influenced by Theodulf's scriptural project, extending our knowledge and understanding of the variety and range of Carolingian biblical scholarship.

Finally, the Newberry fragment shows that manuscript fragments may still reveal much that we know about the Carolingian period. This has also been revealed by the Solothurn fragments of the Theodulf Bible (whose precious content was misidentified by Bischoff's Katalog). It is not impossible that additional fragments of Theodulf's biblical enterprise are lurking among misidentified or uncatalogued manuscript fragments, which are perhaps the most deserving frontier of manuscript research of this generation. 


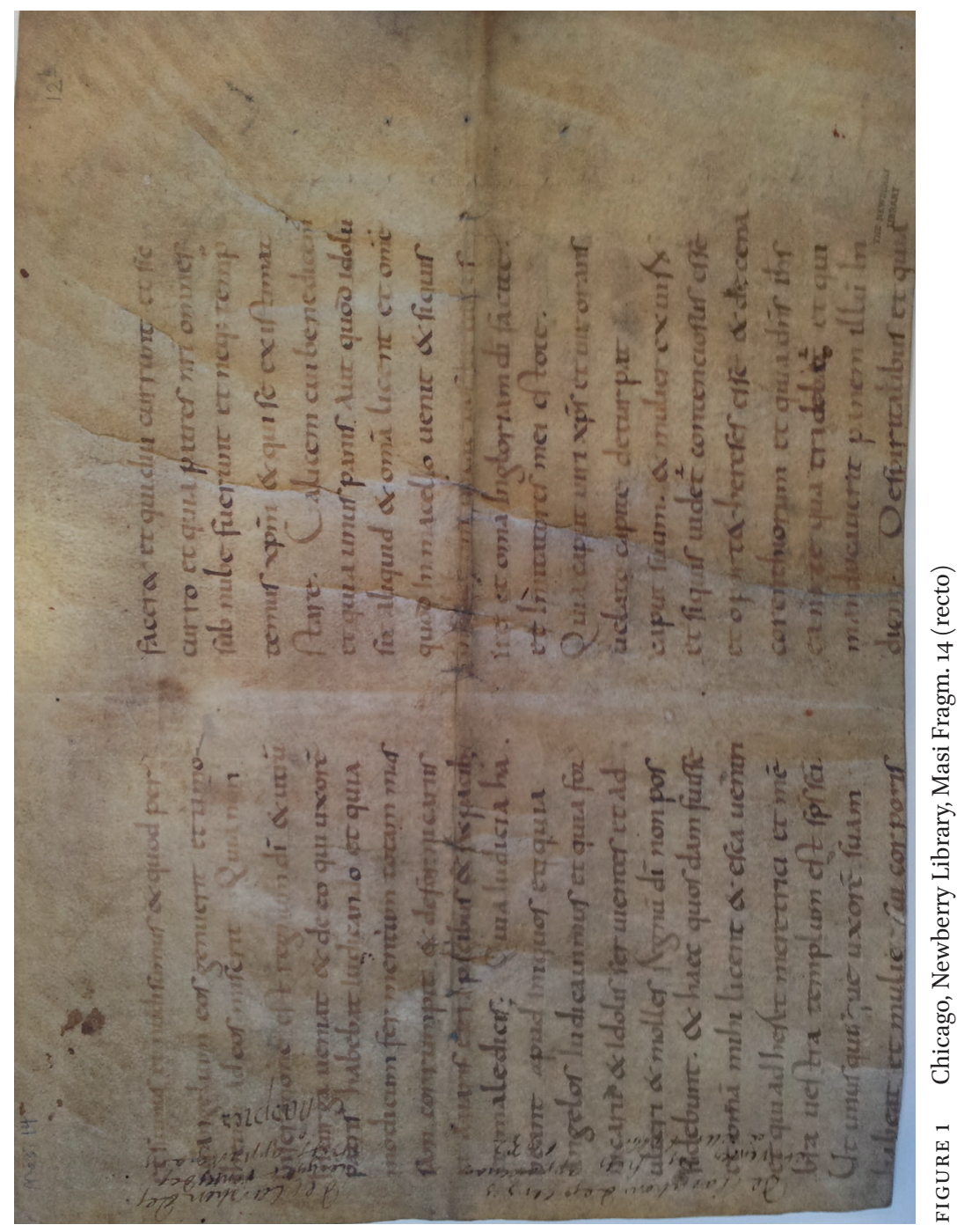

QUÆRENDO 49 (2019) 119-134 


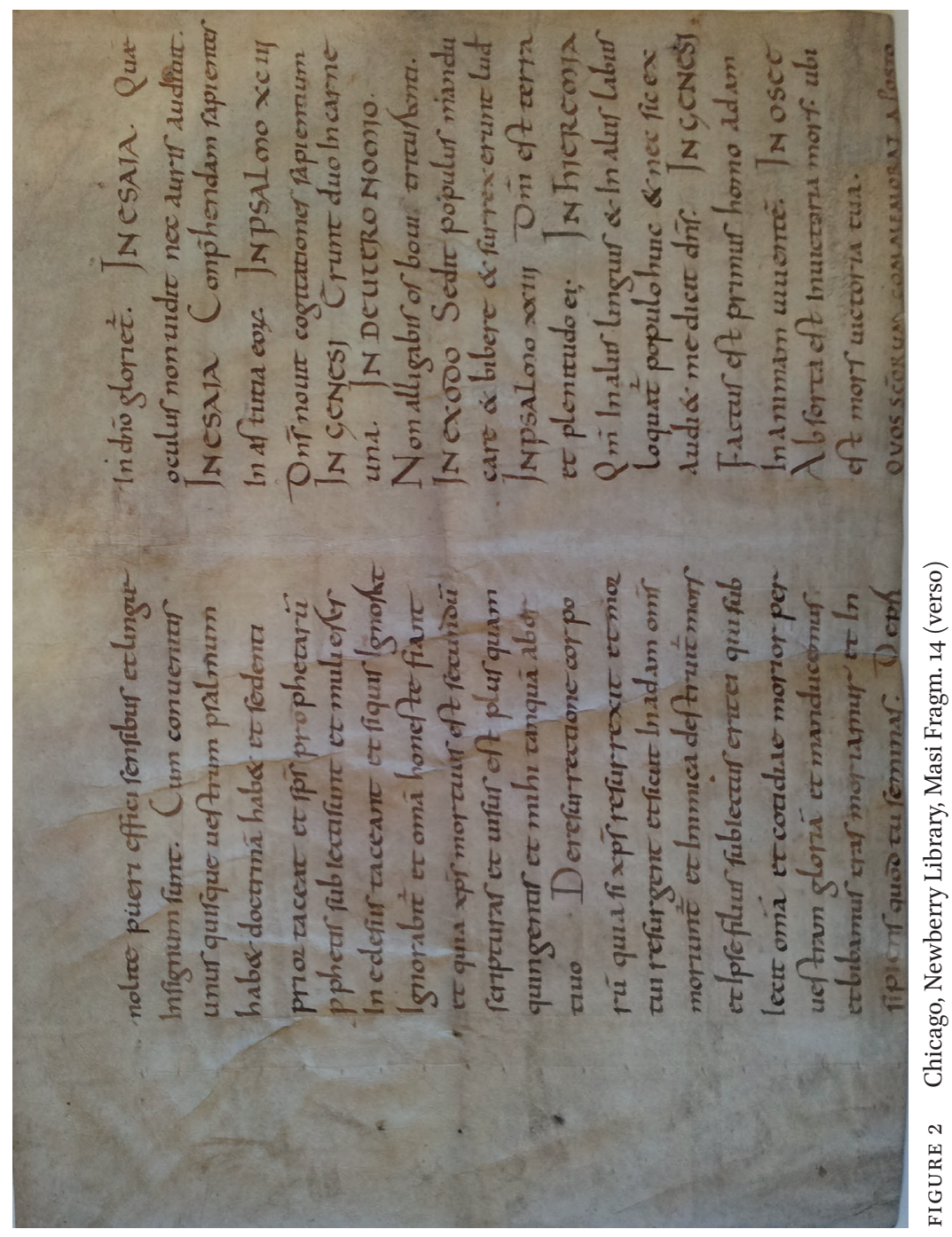

